\title{
Polar axis fixation in Fucus zygotes: components of the cytoskeleton and extracellular matrix
}

\author{
RALPH S. QUATRANO*, LEIGH BRIAN, JOYCE ALDRIDGE and THOMAS SCHULTZ \\ Deparment of Biology, University of North Carolina, Chapel Hill, NC 27599-3280, USA \\ * To whom all correspondence should be addressed.
}

\begin{abstract}
Summary
Polar axis formation and polar axis stabilization (or fixation) can be separated and analyzed in synchronously developing zygotes of the brown alga Fucus. Extensive experimental evidence points to a role for both the cytoskeleton and the extracellular matrix (ECM) in the process of axis fixation in Fucus. A structural complex composed of the cytoskeleton and the ECM has been postulated to stabilize membrane asymmetries generated as a result of axis-forming vectors. This axis stabilizing complex (ASC) may take the form of transmembrane connections between the cytoskeleton on the cytoplasmic face and the ECM on the external side of the plasma membrane, similar to focal contacts in animal cells. At present we know of two components in
\end{abstract}

the proposed ASC of Fucus: an adhesive sulfated glycoprotein which is localized in the ECM, and an actin network which is localized on the adjoining cytoplasmic face. This preliminary report describes evidence for the presence of molecules in two-celled $F$ ucus embryos that are similar to those found in focal contacts in animal cells, i.e. vinculin, integrin and vitronectin. However, their localization and interaction with each other relative to the polar axis has yet to be determined. These initial observations will provide the basis to pursue further an analysis of these components in the process of polar axis fixation.

Key words: polarity, Fucus, integrin, vinculin, vitronectin.

\section{Introduction}

A central problem in developmental biology is to understand the structural basis by which a polar axis is first formed and then stabilized. Zygotes of the brown alga Fucus provide a model system to study the basic mechanisms involved in the generation of zygote/cell asymmetry, stabilization of the resulting polar axis, and directional transport of unique cytoplasmic components to the poles of this axis (Jaffe and Nuccitelli, 1977; Quatrano et al. 1985; Quatrano, 1990). The partitioning of these components into the two daughter cells of the zygote results in a two-celled embryo with clear cellular differentiation - morphological, biochemical, and with respect to their developmental fates (Quatrano et al. 1979). Unlike most eggs, those of the Fucales are apolar with no apparent spatial patterning. 'Polar determinants' are not localized in the egg and rotated by external vectors. In fact, the polar axis arises epigenetically (Jaffe, 1958), and can be easily studied during the synchronous development of these single-celled zygotes in defined culture conditions (Quatrano, 1980). Furthermore, the initial polar axis is labile and can be easily oriented by a number of vectors; the most commonly used experimentally (and likely to be the natural vector) is a gradient of unilateral white light (Jaffe, 1968).

Two components of the photopolarizable axis, i.e. polar axis formation and polar axis stabilization or fixation, can be clearly separated and studied in this synchronously developing system. Zygotes acquire the ability to form an axis between three and seven hours after fertilization, and by $12 \mathrm{~h}$ the axis is fixed. Fixation of the axis occurs before any apparent morphological changes in the single-celled zygote. Prior to axis fixation, the polar axis is labile and can be easily and repeatedly reoriented by imposing a unilateral light gradient from a different direction. Once fixed, localized accumulation of cytoplasmic components occurs directionally, resulting in the initial expression of visible polarity in the zygote by $16 \mathrm{~h}$ (see Quatrano et al. 1979; Quatrano, 1990).

An assay was developed to determine if various antagonists of the cytoskeleton and spindle apparatus interfered with axis fixation (Quatrano, 1973). Previous work using this assay demonstrated that microfilament inhibitors, i.e. the cytochalasins (CB), interfere with axis fixation (Quatrano, 1973; Brawley and Quatrano, 1979), and that a microfilament network composed of actin is localized at or just before emergence of the 
rhizoid (Brawley and Robinson, 1985). Furthermore. Kropf et al. (1989) showed that the timing of filamentous actin localization at the presumptive rhizoid pole coincides precisely with the fixation process and not with the elongation of the rhizoid. Neither microtubules nor protein synthesis, on the other hand, are required for photopolarization (Quatrano, 1973; Brawley and Quatrano, 1979; Kropf et al. 1990).

In addition to the cytoskeleton, the cell wall or extracellular matrix (ECM) plays an essential role in polar axis fixation (Kropf et al. 1988). Kloareg and Quatrano (1987) developed methods to obtain viable zygote protoplasts that can regenerate an ECM and subsequently develop normally into polar, two-celled embryos. Kropf et al. (1988) found that enzymatic removal of the ECM prevents axis fixation. When protoplasts regenerate an ECM, however, the cells regain fixation competence. The requirement for an intact ECM during the fixation process raises the possibility that the ECM provides an external matrix to which the microfilaments are anchored. Hence, a model proposed for axis fixation postulated the formation of transmembrane bridges between cytoskeletal filaments and wall fibrils at the future rhizoid site' (Kropf et al. 1988). Such a structural complex might act to stabilize rearranged membrane components localized as a result of an axis forming gradient such as unilateral white light. Such localized membrane components might include a protein(s) involved in localized tip growth of the rhizoid, or a localized calcium channel or ATPase involved in the generation of an endogenous electric current (Jaffe and Nuccitelli, 1977).

The strong experimental evidence cited above for a role of both the cytoskeleton and the ECM in axis fixation in Fucus has led to a structural model of the site where the first zygotic asymmetries are observed - the location of the future rhizoid tip (Quatrano, 1990). This postulated structural component is termed the AXIS STABILIZING COMPLEX (ASC). Since the tip of the elongating rhizoid becomes the main attachment site of the embryo to a substratum, the proposed ASC (Quatrano, 1990) has similarities to elaborations of the plasma membrane at the site where animal cells adhere to the underlying substratum, i.e. focal adhesions or focal contacts (Burridge et al. 1988). These points of contact between cells and the substratum are composed of transmembrane connections between the cytoskeleton on the cytoplasmic face, and the ECM on the external side of the plasma membrane.

We know of two components in the proposed ASC of Fucus: an adhesive sulfated glycoprotein (F2) which is localized in the ECM only at the tip of the elongating rhizoid (Brawley and Quatrano, 1979), and an actin network which is localized on the adjoining cytoplasmic face (Brawley and Robinson, 1985; Kropf et al. 1989). No other components of the Fucus ASC have been identified.

Complexes similar to the ASC proposed for Fucus have been extensively described and characterized in animal cells. On the extracellular side of these focal contacts, the adhesive glycoproteins fibronectin (FN) or vitronectin (VN) are the localized ECM components, while actin and actin-associated proteins (e.g. vinculin) are localized on the cytoplasmic face. Integrins, the receptors for ECM components and attachment sites for the cytoskeleton, are the integral transmembrane link between the these two networks (Burridge et al. 1988). Other proteins found in these focal contacts play a functional role as sites of transmembrane communication between the extracellular environment and the cytoplasm, e.g. integrins interact with calcium channels, and tyrosine kinases have been found in these focal contacts (see Burridge et al. 1988). Although focal contacts have not been reported in plant cells, Schindler et al. (1989) demonstrated that when extracts of soybean suspension cells are probed with the $\beta 3$ antibody to the transmembrane protein integrin, a single protein $\left(70-72 \times 10^{3} M_{r}\right)$ is detected. No other components of animal focal contacts have been identified in plant cells.

Our objective is to determine if similar molecules exist in Fucus, whether they are localized in the region of the rhizoid tip, and if they play a functional role in axis fixation. This preliminary report describes evidence for the presence of molecules similar to vinculin, integrin and vitronectin in two-celled Fucus embryos.

\section{Materials and methods}

Reproductive tips of Fucus distichus (L.) were collected from Newport, OR, shipped overnight on ice to Chapel Hill, NC. and stored in the dark at $4{ }^{\circ} \mathrm{C}$ for up to four weeks. Shedding of fertilized eggs and growing of zygotes in artificial seawater were performed as previously described (Quatrano, 1980). Two-celled embryos were harvested and stored frozen at $-20^{\circ} \mathrm{C}$ until extraction. Protein was extracted as described by Kropf et al. (1989) and the final straw-colored acetone powder was resuspended in sample buffer, heated to $95^{\circ} \mathrm{C}$ for $5 \mathrm{~min}$. clarified by centrifugation, and stored at $-20^{\circ} \mathrm{C}$. Total protein was assayed by the amido black procedure (Schaffner and Weissmann, 1973) and was typically $2-12 \mu \mathrm{g} \mu \mathrm{l}^{-1}$ in the final extracts.

Protein extracts and standards (High Range Prestained Biorad or Bethesda Research Laboratories) were electrophoresed in a $12.5 \%(\mathrm{w} / \mathrm{v})$ polyacrylamide vertical gel (PAGE) and blotted to Nytran (Schleicher and Schuell) or Hybond $\mathrm{N}$ (Amersham). Blotted proteins were blocked overnight in $8 \%(\mathrm{w} / \mathrm{v})$ nonfat powdered milk or $0.5 \%$ bovine serum albumin in phosphate-buffered saline (PBS) at $4^{\circ} \mathrm{C}$, followed by two $5 \mathrm{~min}$ washes with PBS containing $0.05-0.1 \%(\mathrm{v} / \mathrm{v})$ Tween 20 (PBST). These blots were incubated in primary antibody for $1 \mathrm{~h}$ at room temperature with agitation. After three $10 \mathrm{~min}$ washes in PBST at room temperature with agitation, blots were incubated with secondary antibody for $1 \mathrm{~h}$ at room temperature with agitation, washed again 3 times for $10 \mathrm{~min}$ each in PBST. and developed in $50 \mathrm{mM} \mathrm{NaHCO}_{3}, 10 \mathrm{~mm} \mathrm{MgCl}, 0.15 \mathrm{mg} \mathrm{ml}^{-1} 5$ bromo-4-chloro-3-indolyl phosphate (BCIP) and $0.05 \mathrm{mg} \mathrm{ml}^{-1}$ nitro blue tetrazolium (NBT). When the primary antibody was eliminated in the above procedure, no reactive bands were observed in the protein extracts or authentic standards.

Human anti-vıtronectin (Telios Pharmaceuticals, San Diego, CA) was reconstituted according to instructions in $0.15 \mathrm{M} \mathrm{NaCl}$ and used at a dilution of $1: 250$ in PBST containing 
$2 \mathrm{mg} \mathrm{m}^{-1}$ BSA (PBSTB). Purified human vitronectin (Telios) was reconstituted at $1 \mu \mathrm{g} \mu \mathrm{I}^{-1}$ in PBS and stored at $-20^{\circ} \mathrm{C}$ until use. Anti-integrin $\beta-1$ subunit antibody (a gift of $\mathrm{J}$. Hynes, MIT) (Marcantonio and Hynes, 1988) was used at 1:800 dilution in PBSTB. Chicken vinculin and mouse monoclonal antibodies to chicken vinculin (C19) were gifts from K. Burridge (UNC). A human cell extract was prepared from GM 2291 cells (a gift of T. Tlsty, UNC), and a maize extract was prepared from starch-filled young pollen (Bedinger and Edgerton, 1990). Alkaline phosphatase conjugated anti-mouse (Promega, Madison, WI) and anti-rabbit (Sigma Chemicals, St.Louis, MO) IgG secondary antibodies were used at a $1: 1000$ dilution in PBSTB.

Affinity purification of monospecific antibodies to Fucus using antigen immobilized on filters was performed according to the method of Sambrook et al. (1989), with the following exceptions: the blocking buffer contained $8 \%(w / v)$ non-fat dry milk or $0.5 \%(\mathrm{w} / \mathrm{v}) \mathrm{BSA}$ in PBST; the incubation in blocking buffer was at $4^{\circ} \mathrm{C}$ for $4 \mathrm{~h}$; and all washes were in PBST.

\section{Results and discussion}

When proteins were extracted from two-celled Fucus embryos, separated by PAGE, blotted to a filter and probed with antibodies to vinculin, $\beta-1$ integrin and vitronectin, cross reacting material (CRM) was found for each protein.

\section{Vinculin}

Fig. 1 shows that two different Fucus extracts (lanes 1 and 3) contain CRM to the chicken monoclonal antibody to vinculin. The single band at about $116 \times 10^{3} M_{\mathrm{r}}$ is of a similar relative molecular mass to a standard chicken vinculin (lane 2) and (results not shown) to vinculin in extracts from Xenopus laevis (gift of J. Evans, UNC) (Evans et al. 1990). In separate experiments, we have shown that the antibody which binds to the Fucus protein(s), when isolated and reacted to a blot containing authentic chicken vinculin, recognizes only the $116 \times 10^{3} M_{\mathrm{r}}$ species.

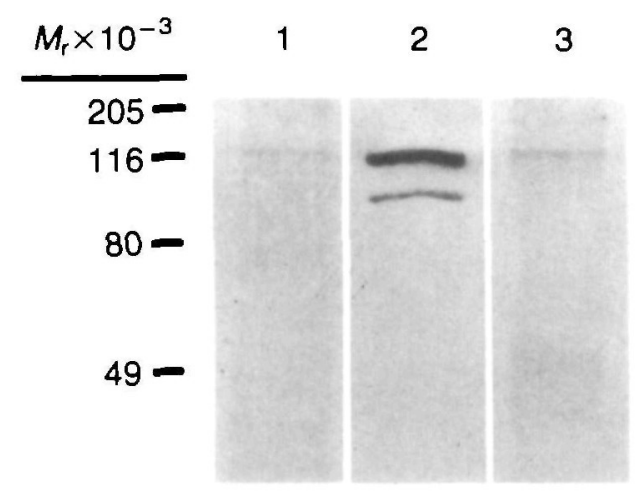

Fig. 1. Protein extracts from two-celled Fucus embryos [lane $1(10 \mu \mathrm{g})$ and lane $3(20 \mu \mathrm{g})$ ] and chicken vinculin standard (lane $2,0.2 \mu \mathrm{g}$ ), were separated by SDS-PAGE, transferred onto nylon membrane, blocked in BSA and probed with antibody to chicken vinculin. Relative molecular mass size markers are indicated.
In focal contacts of animal cells, vinculin is a prominent cytoplasmic component that can interact with other proteins in the cytoskeleton, such as alphaactinin, which crosslinks actin filaments (Burridge et al. 1988; Otto, 1990). Some evidence suggests that vinculin is recruited into the cytoskeletal system at specific developmental stages, perhaps for different functions/ linkages in the apparatus. For example, Evans et al. (1990) demonstrated that in the cytoskeletal system in eggs of Xenopus, the first colocalized detection of vinculin is with talin in the cortex of cleavage furrows and blastomeres. Prior to this time, vinculin is localized in the soluble pool of proteins in the cytoplasm. Hence, the colocalization of vinculin with talin in the cytoskeleton system is a developmentally regulated event that occurs during the transition from oocyte to egg. Vinculin is also delayed in its appearance in the cytoskeleton of the developing chicken gizzard (Volberg et al. 1986). It would be interesting to determine whether the vinculin-like molecule in two-celled Fucus embryos is in the soluble cytoplasm or in the cytoskeletal apparatus, and if this distribution changes during post-fertilization development and the acquisition of a stable polar axis.

\section{Integrin}

In two Fucus extracts ( $\mathrm{F}$ in Fig. 2), a protein species of approximately $92 \times 10^{3} M_{\mathrm{r}}$ was recognized by the antibody to the integrin $\beta-1$ subunit. The $92 \times 10^{3} M_{\mathrm{r}}$ band was significantly smaller than the normal two species $\left(150 \times 10^{3} M_{\mathrm{r}}\right.$ and $132 \times 10^{3} M_{\mathrm{r}}$ - see Hynes, 1987) recognized by the antibody in a human cell extract $(\mathrm{H}$ in Fig. 2). It is likely that the major lower relative molecular mass bands of 66 and $40 \times 10^{3} M_{\mathrm{r}}$ in one of the extracts from Fucus represented protein degradation (cleavage?) products, since the extract with the single

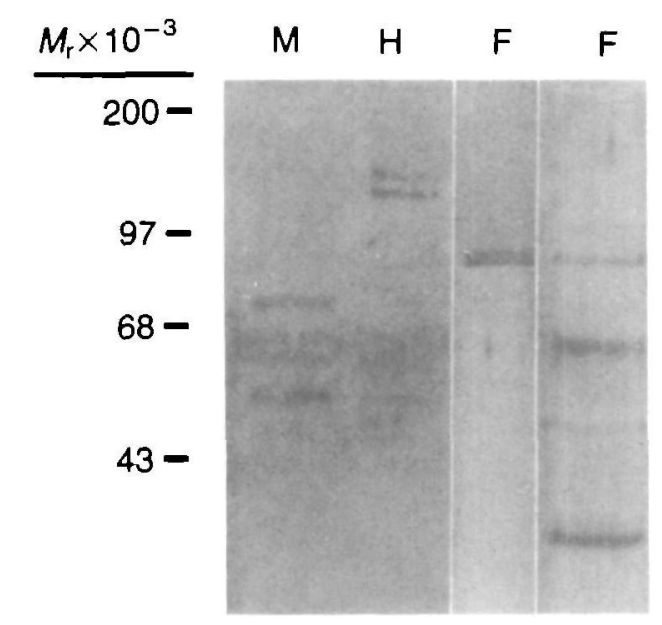

Fig. 2. Protein extracts were separated by SDS-PAGE, transferred onto nylon membrane, and probed with antibody to the $\beta-1$ subunit of integrin: (from left to right) maize pollen $(\mathrm{M}, 40 \mu \mathrm{g})$, human GM 2291 cells $(\mathrm{H}, 3 \mu \mathrm{g})$ and two different extracts from two-celled Fucus embryos, one (right, $2 \mu \mathrm{g}$ ) prepared by our standard procedure (Kropf et al. 1989). Relative molecular mass size markes are indicated. 
protein at $92 \times 10^{3} M_{\mathrm{r}}$ was prepared to minimize proteolysis (i.e. rapid freezing of cells in liquid nitrogen, followed by direct extraction in hot sample buffer). Similar results were obtained by $M$. Schindler (personal communication). An extract from maize pollen ( $\mathrm{M}$ in Fig. 2) yielded two bands at 76 and $55 \times 10^{3} M_{\mathrm{r}}$, the larger species being similar in relative molecular mass to that described by Schindler et al. (1989). These results clearly show that integrin-like molecules are present in plant cells, but extraction procedures to prevent proteolytic cleavage must be developed.

Integrins exist as heterodimers of noncovalently associated $\alpha$ and $\beta$ subunits, and when exposed on the cell surface, provide attachment sites to ECM components such as laminin, fibronectin and vitronectin (Hynes, 1987; Ruoslahti and Pierschbacher, 1987; Buck and Horwitz, 1987). Integrin studies utilize an antibody made to a synthetic peptide corresponding to the $\mathrm{COOH}$-terminal (cytoplasmic) domain of the chicken integrin $\beta-1$ subunit. This antibody also recognizes integrin-like molecules in other vertebrates, as well as Drosophila, the nematode Caenorhabditis elegans, and the yeast Candida albicans (Marcantonio and Hynes, 1988). Integrins also appear to have critical roles in developing organs. Zusman et al. (1990) demonstrate that integrin subunits. which are position-specific antigens of Drosophila, are required for normal development of selected structures, such as wings, eyes and for the proper arrangement of photoreceptor cells.

At least five distinct $\beta$ subunits of integrin have been identified in vertebrate cells (Suzuki et al. 1990). Members of this $\beta$-integrin receptor family are generally within the range of $95-130 \times 10^{3} M_{\mathrm{r}}$ when separated under reducing conditions (Hynes, 1987). The $92 \times 10^{3} M_{\mathrm{r}}$ integrin-like molecule found in Fucus is similar in relative molecular mass to a novel $\beta_{\mathrm{x}}$ subunit found in human carcinoma cells which, in association with the $\alpha_{v}$ subunit, shares structural and functional properties of a vitronectin receptor (Cheresh et al. 1989). While antibodies to the human integrin vitronectin receptor ( $\beta_{3}$ subunit) identified a $70-72 \times 10^{3} M_{\text {r }}$ protein from soybean suspension cells, antibodies to the fibronectin receptor did not recognize the protein (Schindler et al. 1989). This soybean protein was isolated by affinity chromatography to the tripeptide RGD, which is the sequence in various extracellular matrix components (e.g. vitronectin) required for recognition of their plasma membrane receptor, the integrin. The same anti-human vitronectin receptor recognizes a similar protein in Fucus extracts (data not shown). The data from Fucus and soybean suggest that integrin-like proteins exists in plants. If the integrin-like protein found in Fucus is a component of linkages between the ECM and the plasma membrane, it would be interesting to determine if a synthetic peptide containing the RGD sequence could interfere with axis fixation, cell wall regeneration, or the ability of protoplasts to adhere to surfaces coated with ECM components, and whether the integrin-like protein is localized at the rhizoid tip.

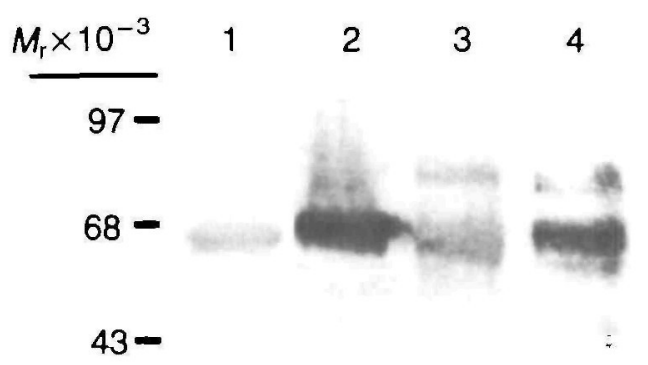

Fig. 3. Protein extract from two-celled Fucus embryos [lane $1(20 \mu \mathrm{g})$ and lane $2(30 \mu \mathrm{g})]$ and human vitronectin standard [lane $3(3 \mu \mathrm{g})$ and lane $4(0.3 \mu \mathrm{g})$ ] were separated by SDS-PAGE, transferred onto nylon membrane, and visualized with antıbody to human vitronectin (lanes 1 and 4). Fucus-specific antibody to vitronectin, which had previously been washed from Fucus lanes (experiment not shown), was reacted against human vitronectin (lane 3 ) and Fucus extract (lane 2). Relative molecular mass size markers are indicated.

\section{Vitronectin}

Polyclonal antibodies to vitronectin recognize CRM in protein extracts of two-celled Fucus embryos, with a major band at $65 \times 10^{3} \mathrm{M}_{\mathrm{r}}$ and a minor one at $75 \times 10^{3} \mathrm{M}_{\mathrm{r}}$ (Fig. 3, lane 1). These bands are similar in relative molecular mass to authentic human vitronectin (Fig. 3, lane 4) and vitronectin extracted from other animals (Kitagaki-Ogawa et al. 1990). When the Fucus-specific rabbit antibody was removed from the bands of Fucus CRM, it specifically recognized the same relative molecular mass band in the same Fucus extract (Fig. 3, lane 2), as well as authentic vitronectin (Fig. 3, lane 3). Sanders et al. (1991) have identified vitronectin-like proteins and mRNA in four species of flowering plants, demonstrating that this substrate adhesion molecule (SAM) apparently has a broad distribution in plant phyla.

The role of plant SAMs is not known, but in Fucus, vitronectin-like molecules may play a role in adhesion of the zygote or rhizoid to the substratum. Such a role would be possible if the vitronectin-like molecule is localized in Fucus rhizoid tips. The sulfated fucan polymer F2 is localized in the ECM of rhizoid tips (see Quatrano et al. 1985), but when prevented from becoming enzymatically sulfated, F2 is not localized in the ECM and the embryos do not adhere to the substratum (Crayton et al. 1974; Hogsett and Quatrano, 1978). F2 is a member of a family of sulfated polysaccharides rich in fucose and similar to heparin sulfate. ECM components of animal cells are known to bind to heparin, and in the case of human vitronectin, a heparin-binding site has been identified at the $\mathrm{COOH}$ terminal end of the protein (Suzuki et al. 1985). If 
similar interactions can be shown between F2 and the vitronectin-like molecule in the ECM of Fucus rhizoid tips, a role for this plant SAM in surface adhesion might be elucidated.

\section{Summary}

Although the results presented and discussed above demonstrate the presence of molecules in two-celled Fucus embryos that are similar to components found in animal focal contacts, their localization in the developing Fucus embryo is unknown. If they play a role in polar axis fixation, their developmental expression, distribution and interactions must be determined, as must evidence that their removal/inactivation prevents axis fixation. The data presented now, however, provide the initial observations and tools to pursue further an analysis of these components in the process of polar axis fixation.

We especially thank our colleagues at UNC, Janice Evans, Brian Kay and Keith Burridge, for their advice and encouragement, as well as for some of the materials and procedures. We are grateful for discussions with Elizabeth Lord, Luraynne Sanders (UC Riverside) and Mel Schindler (Michigan State), and their sharing of unpublished research results. Thanks are also extended to Susan Whitfield (UNC) for her excellent help in preparing the figures. This research was supported by a grant to $\mathrm{R}$. S. Q. from the National Science Foundation (DCB 8917540).

\section{References}

Bedinger, P. A. And Edgerton, M. D. (1990). Developmental staging of maize microspores reveals a transition in developing microspore proteıns. Plant Physiol. 92, 474-479.

Brawley, S. H. and Quatrano, R. S. (1979). Sulfation of fucoidin in Fucus embryos. IV. Autoradiographic investigations of fucoidin sulfation and secretion during differentiation and the effect of cytochalasin treatment. Devl Biol. 73, 193-205.

Brawley, S. H. AND Robinson, K. R. (1985). Cytochalasin treatment disrupts the endogenous currents associated with cell polarization in fucoid zygotes: Studies of the role of F-actin in embryogenesis. J. Cell Biol. 100, 1173-1184.

Buck, C. A. ANd Horwitz, A. F. (1987). Cell surface receptors for extracellular matrix molecules. A. Rev. Cell Biol. 3, $179-205$.

Burridge, K., Fath, K., Kelly, T., Nuckolls, G. and Turner, C. (1988). Focal adhesions: transmembrane junctions between the extracellular matrix and the cytoskeleton. A. Rev. Cell Biol 4, 487-525.

Cheresh, D. A., Smith, J. W., Cooper, H. M. and Quaranta, V. (1989). A novel vitronectin receptor integrin $\left(\alpha_{v} \beta_{\mathrm{x}}\right)$ is responsible for distinct adhesive properties of carcinoma cells. Cell 57, 59-69.

Cratton, M. A., Wilson, E. and Quatrano, R. S. (1974). Sulfation of fucoidan in Fucus embryo. II. Separation from initiation of polar growth. Devl Biol. 39, 164-167.

Evans, J. P., Page, B. D. And Kay, B. K. (1990). Talın and vinculin in the oocytes, eggs and early embryos of Xenopus laevis: a developmentally regulated change in distribution. Devl Biol. 137, 403-413

Hogsett, W. E. and Quatrano, R. S. (1978). Sulfation of fucoidin in Fucus embryos III. Required for localization in the rhizoid wall. J. Cell Biol. 78, 866-873.

Hynes, R. O. (1987). Integrins: a family of cell surface receptors. Cell 48, 549-554.
Jaffe, L. F. (1958). Tropistic responses of zygotes of the Fucaceae to polarized light. Expl Cell Res. 15, 282-299.

JAFFE, L. F. (1968). Localization in the developing Fucus egg.and the general role of localizing currents. Adv. Morphog. 7 , 295-328.

JaFFe, L. F. AND Nuccitelli, R. (1977). Electrical controls of development. A. Rev. Biophys. Bloengng 6, 445-476.

Kitagaki-Ogawa, H., Yatohgo, T., Izumi, M., Hayashi, M. Kashiwagi, H., Matsumoto, I. and Seno, N. (1990). Diversities in animal vitronectuns. Differences in molecular weight. immunoreactivity and carbohydrate chans. Biochim. biophys Acta 1033, 49-56.

Kloareg, B. and Quatrano, R. S. (1987). Isolation of protoplasts from zygotes of Fucus distichus (L.) Powell (Phaeophyta). Plant Sci 50, 189-194.

Kropf, D. L., Berge, S. K. and Quatrano, R. S. (1989). Actin localization during Fucus embryogenesis. Plant Cell 1, 191-200.

Kropf, D. L., Kloareg, B. and Quatrano, R. S. (1988). Cell wall is required for fixation of the embryonic axis in Fucus zygotes. Science 239, 187-190.

Kropf, D. L., MadDoCk, A. And Gard, D. L. (1990). Microtubule distribution and function in early Pelveria development. J. Cell Sci. 97, 545-552.

Marcantonio, E. E. and Hynes, R. D. (1988). Antibodies to the conserved cytoplasmic domain of the integrin $\beta$ subunit react with proteins in vertebrates, invertebrates and fungi. $J \mathrm{Cell}$ Biol. 106, 1765-1772.

Otto, J. J. (1990). Vinculın. Cell Motil. and Cytoskel. 16. 1-6. Quatrano, R S. (1973). Separation of processes associated with differentiation of two-celled Fucus embryos. Devl Bıol. 30. 209-213.

Quatrano, R. S. (1980). Gamete release, fertilızatıon, and embryogenesis in the Fucales. In Handbook of Phycological Methods: Developmental and Cyrological Methods (ed. E. Gantt), pp. 59-68. Cambridge, UK: Cambridge Unıversity Press.

Quatrano, R. S. (1990). Polar axis fixation and cytoplasmic localization in Fucus, In Genetics of Pattern Formation and Growth Control (ed. A. Mahowald), 48th Symposium of The Society for Developmental Biology (U.C. Berkeley). pp. 31-46. New York: Wiley-Liss.

Quatrano, R. S., Brawley, S. H. and Hogsett. W. E. (1979). The control of the polar deposition of a sulfated polysaccharide in Fucus zygotes. In Deterninants of Spatial Orgamzation (eds. S. Subtelny and I. R. Konıgsberg), pp. 77-96. New York: Academic Press.

Quatrano, R. S., Griffing, L. R., Huber-Walchli, V. and Doubet, S. (1985). Cytological and biochemical requirements for the establishment of a polar cell. J. Cell Sci. Suppl 2, $129-141$.

Ruoslahti, E. and Pierschbacher, M. D. (1987). New perspectives in cell adhesion: RGD and integrins. Scrence 238, $491-497$.

Sambrook, J., Fritsch, E. F. and Maniatis, T. (1989). Molecular Cloning. A Laboratory Manual (2nd edition), Book I. Chapter 18. Cold Spring Harbor Laboratory Press: New York.

Sanders, L. A., Wang, C-S., Walling, L. L. and Lord, E M. (1991). A homolog of the substrate adhesion molecule vitronectin, occurs in four species of flowering plants. Plant Cell 3 in press

Schaffner, W. and Weissmann, C. (1973). A rapid. sensitive, and specific method for the determination of protein in dilute solution Anal. Btochem 56, 502-514

Schindler, M., Meiners, S. And Cheresh. D. A (1989). RGDdependent linkage between plant cell wall and plasma membrane: Consequences for growth $J$. Cell Biol. 108 1955-1965.

Suzuki, S., Huang, Z-S. And Tanihara, H. (1990). Cloning of an integrin $\beta$ subunit exhibiting high homology with integrin $\beta_{3}$ subunit. Proc. nath. Acad. Sci. U.S.A. 87. 5354-5358.

Suzuki, S., Oldberg, A.. Hayman. E. G.. Pierschbacher. M. D. and Ruoslahti, E (1985). Complete amino acid sequence of 
human vitronectin deduced from cDNA. Similanty of cell attachment sites in vitro nectın and fibronectın. EMBO J. 4 $2519-2524$.

Voleerg, T., Sabanay, H. and Geiger, B. (1986). Spatial and temporal relationships between vinculin and talin in the developing chicken gizzard smooth muscle. Differentianion 32 $34-43$.

Zusman, S., Patel-King, R S., Ffrench-Constant, C. and

HYNes, R. O. (1990). Requirements for integrins during Drosophila development Developmem 108, 391-402 